\title{
Foraging behavior of the giant honey bee, Apis dorsata F. (Hymenoptera: Apidae) in sunflower (Helianthus annuus L.) at Peshawar District of Pakistan
}

\author{
Fazal Said, Fazal Jalal*, Muhammad Imtiaz, Muhammad Ali Khan and \\ Sayed Hussain \\ Department of Agriculture, Abdul Wali Khan University, Mardan-Pakistan \\ *Corresponding author's email: $\underline{\text { r.fazal@awkum.edu.pk }}$
}

Citation

Fazal Said, Fazal Jalal, Muhammad Imtiaz, Muhammad Ali Khan and Sayed Hussain. Foraging behavior of the giant honeybee, Apis dorsata F. (Hymenoptera: Apidae) in sunflower (Helianthus annuus L.) at Peshawar District of Pakistan. Pure and Applied Biology. Vol. 7, Issue 3, pp1115-1121. http://dx.doi.org/10.19045/bspab.2018.700130

\begin{tabular}{llll}
\hline \hline Received: 02/04/2018 & Revised: 10/07/2018 & Accepted: 01/08/2018 & Online First: 04/08/2018
\end{tabular}

\section{Abstract}

Foraging of honey bee is of great importance from pollination point of view, as sunflower production mainly depends on insect visitors in common and honeybee in particular. Keeping in view the importance of pollinators, foraging behavior of the Giant Honey bee, Apis dorsata in sunflower, Helianthus annииs L. at Peshawar District was studies at New Developmental Farm (NDF), The University of Agriculture Peshawar, $\left(34.01^{\circ} \mathrm{N}, 71.53^{\circ}\right.$ E) Khyber Pakhtunkhwa (KP), Pakistan during 2012 and 2013. Observation on foraging activities of honeybee recorded from morning hours i.e. $0800 \mathrm{hr}$ and continued until $1800 \mathrm{hr}$ of the day. It was found that foraging of honey bee varied greatly during different hours of the day. Maximum foraging of $A$. dorsata species recorded at $1600 \mathrm{hr}$ and followed by another peak foraging activities of bee visitors at 1200 noon. Minimum foraging activities found at $1800 \mathrm{hr}$. It was also learnt that foraging of bee visitors' greatly affected by the amount of pollens and nectars on blossoms of sunflower. During $20^{\text {th }}$ and $25^{\text {th }}$ days after flowering on the crop, maximum individuals of $A$. dorsata recorded since numerous plants were in full bloom. Similarly, less number of bees found while foraging as the crop moved toward maturity. It was concluded that sunflower is such a crop that attracts honeybees which helps in cross-pollination of the crop and ultimately increase grain yield as well as enhance quality of the produce as well. Farmer communities hence should advise to avoid extensive use of insecticides during blossoming stage in order to protect honeybees and other natural enemies.

Keywords: Apis dorsata; Foraging; Pakistan; Pollination; Sunflower

\section{Introduction}

Insect visitors pollinate more or less $90 \%$ of various flowering plant species across the world [1]. Pollinators have been the major source while determining the mating prospects of crops. In terms of pollination, many plant species are generalists $[2,3]$ and rely on numerous pollinator species. Among pollinators, honeybees (Apis spp.) are generally considered the most important and 
leading pollinator species associated with a wide range of economically important crop species worldwide. Wide range of host range enables honeybees to pollinate several types of crops. As compared to many other insect visitors, honeybees have longest visit time to flowers and less affected by adverse weather conditions. Their close relation to a lot of of imperative crops and its foraging behavior makes them successful insect pollinators. Honeybees are reported to have an indispensable role in enhancing the competence level of many crops including most of seed species crops [4-6].

The improved quality of grains and fruits in different crop has been observed when these crops were visited by managed honeybee colonies [7]. Honeybee pollination may increase fruit set percentage by 10 to 25 per cent and fruit yield by 18 to 100 per cent depending upon the cultivar $[8,9]$. Sunflower is such a crop that is generally fertilized by wind, even though, the wind is considered as the chief pollinator for many flowering plants, yet it is not enough for pollination on many kinds of plants including sunflower $(H$. annuus L.) because it is not competent to offer homogenous pollination as well as not being able to carry heavy pollens [10-12].

Worker bees of $A$. dorsata forage less number of pollens from different flowers than that of $A$. mellifera, which forage and carry huge pollen loads from flowers. However, A. dorsata individuals forage heavier pollens during early morning hours [13]. According to [14] Population density of A. dorsata species is declining due to many reasons like widespread insertion and endorsement of $A$. mellifera individuals by public and private sector through developmental intrusion, alteration in their habitat and biodiversity. Non-judicious application of chemical pesticides, diseases and parasites attack etc are also mainly responsible for low incidence of $A$. dorsata species. As per report of [15] among different species of honeybee, such as domesticated bee species Apis mellifera and Apis cerana have extraordinary significance since their inhabitants can be easily managed accordingly to need of crops and duration of blooming period. In addition to these domesticated honeybee species, wild honeybee, Apis dorsata also play essential role in many fruit and seed crops.

Keeping in mind the importance of bee visitants, the present research study was therefore, conducted with the intention to determine the foraging pattern and population density of the Giant honeybee $(A$. dorsata) in Peshawar District of Khyber Pakhtunkhwa (KP).

\section{Materials and methods}

Present investigation on foraging behavior of Giant Honeybee, A. dorsata on sunflower was carried out at the New Developmental Farm (NDF) of the University of Agriculture Peshawar $\left(34.01^{\circ}\right.$ North latitude and $71.53^{\circ}$ East longitude) during 2012 and 2013. Sunflower Hybrid Hysun-33 was grown during spring and autumn seasons and standard agronomical practices were adopted while sowing the crop. The experimental area was kept free from any pesticide application during the flowering period of the crop.

The experiment was laid out in Randomized Complete Block (RCB) design and was replicated four times. Plot size was kept $3 \times$ $3 \mathrm{~m}^{2}$ with 5 rows that were $60 \mathrm{~cm}$ apart from each other. Plant-to-plant distance was maintained $30 \mathrm{~cm}$ respectively. The following parameter was studied during experiment:

\section{Population density of Apis dorsata on sunflower Hysun-33}

As per procedure adopted by [16] observation on bee visits to sunflower blossoms was taken from commencement of 5 per cent flowering on the crop and last until $35^{\text {th }}$ days after inflorescence. Daily 
observation of bee visitors after a gap of 5 days was recorded 6 times at 0800, 1000, 1200, 1400, 1600 and $1800 \mathrm{hr}$ of the day. Observations were recorded on total number of bee individuals for 5 minutes on 10 randomly selected capitula in four different spots having area of $3 \times 3 \mathrm{~m}^{2}$ and thus mean bee visits was calculated.

\section{Statistical analysis}

After recording observations, the collected data were analyzed according to the procedure appropriate for randomized complete blocked design (RCBD) combine over year and season by using statistical software, Gen-Stat third edition. Least significance test was performed for separation of means when the F- test was found significant, as outlined by [17].

\section{Results}

Foraging activity of Apis dorsata on sunflower Hysun-33 during spring 201213

Data on foraging behavior/ pattern of honeybees on selected crop at different time intervals revealed that 5 days after initiation of flowers on the crop, it was found that individuals (4.37) of $A$. dorsata were most active during noon at $1600 \mathrm{hr}$, which was followed by second peak (3.62) of foraging activities at $1200 \mathrm{hrs}$. Lowest (1.37) foraging activity was found at $1800 \mathrm{hrs}$ of the day (Table 1). After an interval of 10 days of 5 percent blooming on the crop, inhabitants of $A$. dorsata constituted maximum (4.75) density at $1600 \mathrm{hr}$, which was followed by mean frequency of 4.12 at 1200 noon. Minimum foraging activities of honeybee recorded with 1.75 bee visitors at 0800 hrs. $15^{\text {th }}$ day after flowering, the foraging activity of $A$. dorsata started at $0800 \mathrm{hr}$ with 2.87 bees $/ \mathrm{m}^{2} / 5 \mathrm{~min}$. population density of honeybee recorded on its peak (5.37) at $1600 \mathrm{hr}$. Second peak foraging of bee visitors observed with average population of 4.50 at 1200 noon. Minimum strength was recorded with 2.25 bees at
1800 hrs of the day. On $20^{\text {th }}$ day of 5 per cent of flowering on the crop, A. dorsata individuals foraging activities were observed with 5.25 bees per $3 \mathrm{~m}^{2}$ area for 5 minutes at $1600 \mathrm{hr}$ that was followed by 5.25 and 4.62 count of bee visitants at 1200 and $1000 \mathrm{hr}$ respectively. The foraging activities declined to least count of 2.75 bees at 1800 $\mathrm{hr}$ during evening hours of the day. It is evident from (Table 2) that $25^{\text {th }}$ day after flowering, the first peak (5.87) of foraging activities of $A$. dorsata recorded at 1600 and second peak of bee visitants noticed with mean count of 5.25 honeybees at 1200 noon. Similarly, the least activity was found at $1800 \mathrm{hr}$, which recorded only 2.50 bees $/ \mathrm{m}^{2} / 5 \mathrm{~min}$. On $30^{\text {th }}$ day after crop blooming stage, it was noticed that highest bee visitation was occurred at 1600 noon with average number of 4.37 bees, which was followed by a second peak of 3.75 individuals of $A$. dorsata at $1200 \mathrm{hrs}$ of the day. Less foraging activities of bees were observed during late hours and was found that mean number of 1.12 bees were engaged in foraging at $1600 \mathrm{hrs}$. Foraging activities of $A$. dorsata on sunflower after 35 days of crop flowering stage showed that their incidence declined due to maturity of crop and less availability of pollens and nectar on flowers. However, highest (3.25 and 2.87) mean counts of bee individuals were made at 1600 and $1200 \mathrm{hr}$ respectively. Lowest (0.87) foraging was found at 1800 hrs of the day.

Foraging activity of Apis dorsata on sunflower Hysun-33 during autumn 20122013

A. dorsata was most prevalent (3.00 bees $/ 3 \mathrm{~m}^{2} / 5 \mathrm{~min}$ ) at $1600 \mathrm{hr}$. of the day that was followed by 2.37 at 1200 noon. Minimum count of honeybees was recorded with $0.87 \mathrm{bees} / 3 \mathrm{~m}^{2} / 5$ minutes at $1800 \mathrm{hrs}$ of the day. On 10th day after flowering, $A$. dorsata foraging activities were observed with highest count of 3.25 bees per $3 \mathrm{~m}^{2}$ 
area for 5 minutes at $1600 \mathrm{hrs}$ of the, which was further followed by a mean population of 3.00 bees at $1200 \mathrm{hr}$. minimum incidence recorded with 1.25 at $1800 \mathrm{hr}$ during evening hours of the day. Data regarding mean incidence of bee visitors recorded on 15 days after flowering revealed that first peak of $A$. dorsata foraging activity recorded at $1600 \mathrm{hr}$ of the day with 3.62 bees whereas second peak foraging activity was found at $1200 \mathrm{hr}$ with 3.25 bees. Minimum activity of bees was found at 1800 hrs, which recorded only 1.75 individuals of A. dorsata. After $20^{\text {th }}$ day of flowering, it was found that highest (4.50) mean frequency of $A$. dorsata individuals were recorded at $1600 \mathrm{hr}$ of the day. The next peak foraging observed with 4.02 bees $/ 3 \mathrm{~m}^{2} / 5$ minutes at $1200 \mathrm{hr}$. Lowest (2.25) population of bees was found at 1800 hr of the day. On $25^{\text {th }}$ day after crop, blooming stage maximum foraging recorded at $1600 \mathrm{hr}$ with mean number of 4.25 bees, which was followed by a second peak of 3.87 individuals of $A$. dorsata at $1200 \mathrm{hrs}$ of the day. Minimum counts with 2.37 bees $/ 3 \mathrm{~m}^{2} / 5$ minutes noticed at $1800 \mathrm{hrs}$ of the day. On $30^{\text {th }}$ day after flowering, the first peak (3.37 bees $/ 3 \mathrm{~m}^{2} / 5$ minutes) of foraging activities of $A$. dorsata found at $1600 \mathrm{hr}$. second peak of bee visitants observed with a mean count of 3.00 individuals at 1200 noon. An average count on only 1.12 bees recorded at $1800 \mathrm{hr}$ of the day. On $35^{\text {th }}$ day after crop blooming stage, it was found that significantly more (2.75) number of bee recorded at $1600 \mathrm{hr}$, which was followed by 2.37 bees at $1200 \mathrm{hr}$. Minimum (0.75) foraging activity was recorded at $1800 \mathrm{hrs}$ of the

day.

Table 1. Population density of Apis dorsata on Sunflower during spring 2012-2013

\begin{tabular}{|c|c|c|c|c|c|c|c|}
\hline \multirow{2}{*}{$\begin{array}{c}\text { Hours of the } \\
\text { Day }\end{array}$} & \multicolumn{7}{|c|}{ Interval x Treatment x Season } \\
\cline { 2 - 8 } & 5DAF & 10 DAF & 15 DAF & 20 DAF & 25 DAF & 30 DAF & 35 DAF \\
\hline 0800 & $1.62 \mathrm{x}-\mathrm{zab}$ & $2.25 \mathrm{~s}-\mathrm{x}$ & $2.87 \mathrm{n}-\mathrm{t}$ & $3.62 \mathrm{~h}-\mathrm{n}$ & $3.37 \mathrm{j}-\mathrm{p}$ & $2.37 \mathrm{r}-\mathrm{x}$ & $1.75 \mathrm{w}-\mathrm{za}$ \\
\hline 1000 & $3.12 \mathrm{l}-\mathrm{r}$ & $3.75 \mathrm{~g}-\mathrm{m}$ & $4.00 \mathrm{e}-\mathrm{k}$ & $4.62 \mathrm{c}-\mathrm{f}$ & $4.37 \mathrm{e}-\mathrm{h}$ & $3.25 \mathrm{k}-\mathrm{q}$ & $2.25 \mathrm{~s}-\mathrm{x}$ \\
\hline 1200 & $3.62 \mathrm{~h}-\mathrm{n}$ & $4.12 \mathrm{e}-\mathrm{j}$ & $4.50 \mathrm{~d}-\mathrm{g}$ & $5.25 \mathrm{~b}-\mathrm{d}$ & $5.25 \mathrm{~b}-\mathrm{d}$ & $3.75 \mathrm{~g}-\mathrm{m}$ & $2.87 \mathrm{n}-\mathrm{t}$ \\
\hline 1400 & $2.62 \mathrm{p}-\mathrm{v}$ & $3.12 \mathrm{l}-\mathrm{r}$ & $3.25 \mathrm{k}-\mathrm{q}$ & $3.87 \mathrm{f}-\mathrm{l}$ & $4.00 \mathrm{e}-\mathrm{k}$ & $2.62 \mathrm{p}-\mathrm{v}$ & $2.00 \mathrm{u}-\mathrm{z}$ \\
\hline 1600 & $4.37 \mathrm{e}-\mathrm{h}$ & $4.75 \mathrm{c}-\mathrm{e}$ & $5.37 \mathrm{a}-\mathrm{c}$ & $6.12 \mathrm{a}$ & $5.87 \mathrm{a}-\mathrm{b}$ & $4.37 \mathrm{e}-\mathrm{g}$ & $3.25 \mathrm{k}-\mathrm{q}$ \\
\hline 1800 & $1.37 \mathrm{yza}-\mathrm{c}$ & $\begin{array}{c}1.75 \mathrm{w}- \\
\text { za }\end{array}$ & $2.25 \mathrm{~s}-\mathrm{x}$ & $2.75 \mathrm{o}-\mathrm{u}$ & $2.50 \mathrm{q}-\mathrm{w}$ & $1.12 \mathrm{a}-\mathrm{c}$ & $0.87 \mathrm{bc}$ \\
\hline
\end{tabular}

Means within columns followed by the same letter are non-significant at 5\% level of probability

$\mathrm{LSD}_{0.05}$ for $\mathrm{SxT} \mathrm{TI}=0.92$

$\mathrm{DAF}=$ Days after flowering

Table 2. Population density of Apis dorsata on Sunflower during autumn 2012-2013

\begin{tabular}{|c|c|c|c|c|c|c|c|}
\hline \multirow{2}{*}{$\begin{array}{c}\text { Hours of the } \\
\text { Day }\end{array}$} & \multicolumn{7}{|c|}{ Interval x Treatment x Season } \\
\cline { 2 - 8 } & 5DAF & 10 DAF & 15 DAF & 20 DAF & 25 DAF & 30 DAF & 35 DAF \\
\hline 0800 & $1.12 \mathrm{a}-\mathrm{c}$ & $1.75 \mathrm{w}-\mathrm{za}$ & $2.25 \mathrm{~s}-\mathrm{x}$ & $2.87 \mathrm{n}-\mathrm{t}$ & $2.87 \mathrm{n}-\mathrm{t}$ & $1.75 \mathrm{w}-\mathrm{za}$ & $1.25 \mathrm{za}-\mathrm{c}$ \\
\hline 1000 & $2.12 \mathrm{t}-\mathrm{y}$ & $2.75 \mathrm{o}-\mathrm{u}$ & $3.00 \mathrm{~m}-\mathrm{s}$ & $3.50 \mathrm{i}-\mathrm{o}$ & $3.62 \mathrm{~h}-\mathrm{n}$ & $2.75 \mathrm{o}-\mathrm{u}$ & $2.00 \mathrm{u}-\mathrm{z}$ \\
\hline 1200 & $2.37 \mathrm{r}-\mathrm{x}$ & $3.00 \mathrm{~m}-\mathrm{s}$ & $3.25 \mathrm{k}-\mathrm{q}$ & $4.00 \mathrm{e}-\mathrm{k}$ & $3.87 \mathrm{f}-\mathrm{l}$ & $3.00 \mathrm{~m}-\mathrm{s}$ & $2.37 \mathrm{r}-\mathrm{x}$ \\
\hline 1400 & $1.87 \mathrm{v}-\mathrm{za}$ & $2.50 \mathrm{q}-\mathrm{w}$ & $2.62 \mathrm{p}-\mathrm{v}$ & $3.25 \mathrm{k}-\mathrm{q}$ & $3.37 \mathrm{k}-\mathrm{p}$ & $2.37 \mathrm{r}-\mathrm{x}$ & $1.87 \mathrm{v}-\mathrm{za}$ \\
\hline 1600 & $3.00 \mathrm{~m}-\mathrm{s}$ & $3.25 \mathrm{k}-\mathrm{q}$ & $3.62 \mathrm{~h}-\mathrm{n}$ & $4.50 \mathrm{~d}-\mathrm{g}$ & $4.25 \mathrm{e}-\mathrm{i}$ & $3.37 \mathrm{j}-\mathrm{p}$ & $2.75 \mathrm{o}-\mathrm{u}$ \\
\hline 1800 & $0.87 \mathrm{bc}$ & $1.25 \mathrm{za}-\mathrm{c}$ & $1.75 \mathrm{w}-\mathrm{za}$ & $2.25 \mathrm{~s}-\mathrm{x}$ & $2.37 \mathrm{r}-\mathrm{x}$ & $1.12 \mathrm{a}-\mathrm{c}$ & $0.75 \mathrm{c}$ \\
\hline
\end{tabular}

Means within columns followed by the same letter are non-significant at $5 \%$ level of probability

$\mathrm{LSD}_{0.05}$ for $\mathrm{SxTxI}=0.92$

$\mathrm{DAF}=$ Days after flowering 


\section{Discussion}

Maximum foraging activity of the $A$. dorsata observed at $1600 \mathrm{hr}$ and was followed by 1200 noon. Second peak foraging activities of $A$. dorsata individuals were recorded at $1000 \mathrm{hr}$. of the day. It was noticed that foraging activities of Giant honeybee occurred during mid-day hours. Floral glands producing the nectars that are highly active during mid-day timings and resulted in abundant bee foraging at 1600 and 1200 noon. During the whole blossoming period of the crop, foraging activities were normally observed, however, the uppermost foraging activities of the $A$. dorsata individuals was seen during $20^{\text {th }}$ and $25^{\text {th }}$ day after inflorescence of sunflower. Minimum bee foraging activities recorded on $5^{\text {th }}$ and $10^{\text {th }}$ day that was probably due to few plants were in blossom stage. In the same way, during $30^{\text {th }}$ and $35^{\text {th }}$ day after flowering on the crop, significantly low prevalence was noticed, which may be due to end of flowering season and due to maturity of the crop and because of fewer pollen and nectar accessibility on the flowers. The conclusion of current study are in close agreement with that of [18] who stated that $A$. dorsata were dynamically involved in foraging at $0905 \mathrm{hr}$ to 1615 on cotton crop. [19] also observed parallel results on $A$. dorsata foraging activity from 0800 to $1600 \mathrm{hrs}$ of the day on $B t$ cotton. [20] found peak foraging pattern of $A$. dorsata at 1200 noon. Similarly, [21] noticed highest foraging of $A$. dorsata individuals at 1200 noon on inflorescence of $B t$ cotton. [22] found greatest foraging of $A$. dorsata species from 1100 and $1200 \mathrm{hr}$ on capitulum of sunflower. [23] further confirm our findings that foraging of $A$. dorsata was recorded throughout the day. The time spent by bee visitors in order to feed on the blossoms mainly depends on the presence of nectar and pollen on the flowers. In addition, foraging of honeybees also varies with the type of flower on which they feed and the stage of its growth with climatic conditions. It observed that the time spent on the flowers by $A$. dorsata was more during midday hours of the day. This agree with the previous results recorded by [24] who reported that different insect visitants are generally forage on the flowers between 0900 through $1200 \mathrm{hrs}$ of the day.

\section{Conclusion and recommendation}

Based on the outcome of the present investigations, it could be concluded that the blossoms of sunflower attract rich fauna of different insect visitors in which, the honeybees constituted the major group of pollinators. Honeybees play a vital role in successful production of sunflower seeds, which not only increase grain yield but also improve quality of the grains significantly. Highest density/foraging of A. dorsata individuals were recorded during 1600 and 12000 noon of the day that greatly helped in cross-pollination of the crop. Pollination services provided by honeybees may be helpful in enhancing seed yield in sunflower and possibly in many other fruit and seed species crops. Since large number of honeybee's forage sunflower capitula during its blooming stage, which not only enhance grain yield but also improve quality of the produce as well. Farmer communities therefore, should advise to avoid widespread use of insecticides when crops are in blossoming stage to protect pollinator species and other natural enemies.

\section{Authors' contributions}

Conceived and designed the experiments: F Said, Performed the experiments: F Said, Analyzed the data: F Jalal, Contributed materials/ analysis/ tools: M Imtiaz, MA Khan \& S Hussain, Wrote the paper: F Said. Acknowledgements

The author extends sincere gratitude to Prof. Dr. Mian Inayatullah, Chairman, Department of Entomology for the technical support throughout the experiment and Farm 
Manager, New Developmental Farm (NDF) for providing experimental plot. The financial assistance provided by the Higher Education Commission (HEC) Islamabad, Government of Pakistan is also highly acknowledged.

\section{References}

1. Buchmann SL \& Nabhan GP (1996). The Forgotten Pollinators. (Island Press/Shearwater Books: Washington DC).

2. Waser NM, Chittka L, Price MV, Williams NM \& Ollerton J (1996). Generalization in pollination systems, and why it matters. Ecology 77: 10431060.

3. Olesen JM (2000). Exactly how generalised are pollination interactions? In 'The Scandinavian Association for Pollination Ecology honours Knut Fægri'. (Eds Totland, WS Armbruster, C Fenster,

4. Choudhary OP \& Singh J (2007). Diversity, temporal abundance, foraging behavior of floral visitors and effect of different modes of pollination on coriander (Coriandrum sativum L.). $J$ of Spice Aeromatic Crops 16(1): 8-14.

5. Abrol DP (1991). Conservation of pollinator for promotion of agriculture production in India. J Anim Morphol Physiol 38(1/2): 123-139.

6. Singh MP, Singh KI \& Devi CS (2000). Foraging behaviour of Apis cerana Himalaya for sunflower and rape seed. In: Asian Bees and Beekeeping, Progress of Research and Development. (eds.) Matsuka M, Verma LR, Wongsiri S, Shrestha KK \& Partap U ICIMOD, Kathmandu 2000. pp 199-202.

7. Pratap U \& Verma LR (1994). Pollination of radish by Apis cerana. $J$ of Apiculture Res 33:237-241.

8. Moeller FE \& Koval CF (1973). Honeybee Pollination of Strawberries in Wisconsin. Resource Report, Co- operative Extension, University of Wisconsin No. 2549.

9. Free JB (1970). Insect pollination of crops. Academic Prees, London 1970. pp 544.5 DOI 10.1017/S0014479700023401.

10. Parker FD (1981). Sunflower pollination, abundance, diversity and seasonality of bees and their effect on seed yields. $J$ of Apiculture Res. 20(1): 49-61.

11. Freund DE \& Furgula B (1982). Effect of pollination by insects on the seed set and yield of ten oilseed sunflower cultivars. Am Bee J 122(9): 648-652.

12. ICIMOD (2001). Indigenous Honeybee of the Himalayas: A Community Based Approach to Conserving Biodiversity and Increasing Farm Productivity. Six Monthly Progress Reports. ICIMOD, Kathmandu, Nepal.

13. Sihag RC (1986). Insect pollination increase seed production in cruciferous and umbelleferous crops. $J$ of Apiculture Res 25(2):121-126.

14. Steel RGD, Torrie TJ \& Dickey DA (1997). Principles and procedures of statistics: A biometrical approach. 3rd ed. McGraw Hill book Co. Inc. New York. pp 400-428.

15. Ahmed B \& Rehman A (2002). Population dynamics of insect foragers and their effect on seed yield of rapeseed (Brassica campestris L. var. toria). Indian Bee J 64(3 \& 4): 1-5.

16. Corlett RT( 2004). Flower visitors and pollination in the Oriental (Indomalayan) Region. Biological Rev 79(3): 497-532.

17. Joshi SR (2000). Pollination of red leaf mustard by Apis cerana F. Ecoprint. 7(1):63-67.

18. Kopel'kievskii GV (1953). Timely locations of bees for pollinations of buckwheat and the honey crop. Pchelovodstvo. Mosk 30: 28-31. 
19. Mishra RC (1997-98). Perspectives in Indian apiculture. Agro. Botanica, HS Offset Printers, New Delhi. pp188.

20. Molau U, Nilsson LA, Olesen, JM, Ollerton J, Philipp J \& Ågren J. The Norwegian Academy of Science and Letters: Oslo. pp 161-178.

21. Nye WP \& Anderson JL (1974). Insect pollinators frequenting strawberry blossoms and the effect of honeybees on yield and fruit quality. $J$ of American Society of Horticultural Sci 99: 40-44.

22. Panda P, Rath LK, Padhi J \& Panigrahi D (1995). Relative abundance and foraging behavior of common bee species on niger in Phulbani district, Orissa, India. Indian Bee J 57: 10-14.

23. Solov'ev GM (1960). Use of some characteristics of the interrelation between bees and entomophilous plants. Agrobiologiya 6: 939- 942.

24. Verma LR \& Partap U (1994). Foraging behavior of Apis cerana on cauliflower and cabbage and its impact on seed production. $J$ of Apiculture Res 33(4): 231-236. 